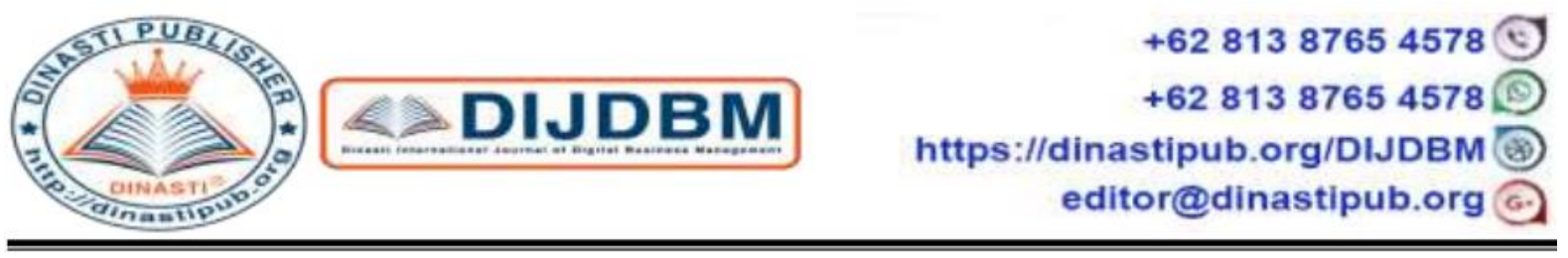

\title{
EVALUATION OF THE IMPLEMENTATION OF INTERNAL CONTROL SYSTEM FOR THE RECEPTION, RETURN AND AUCTION OF GUARANTEE GOODS IN. PEGADAIAN (PERSERO)
}

\author{
Ahmad Raymond Trilaksana ${ }^{1)}$ \\ 1) Universitas Mercubuana, Jakarta, Indonesia
}

\begin{tabular}{|c|c|}
\hline $\begin{array}{l}\text { ARTICLE INFORMATION } \\
\text { Received: } 26 \text { December } 2019 \\
\text { Revised: } 31 \text { December } 2019 \\
\text { Issued: } 7 \text { January } 2020 \\
\text { Corresponding author: } \\
\text { Ahmad Raymond Trilaksana } \\
\text { DOI:10.31933/DIJDBM }\end{array}$ & $\begin{array}{l}\text { Abstract: PT. Pegadaian (Persero) provides loans to people } \\
\text { with require collateral item as insurance. PT. Pegadaian have } \\
\text { to keep the collateral save and maintain it secure, so that } \\
\text { internal control for collateral items are necessary needed. } \\
\text { The purpose of this research was to determine and evaluate } \\
\text { the implementation of the internal control systems for } \\
\text { receiving, returns, and auctions of collateral items at PT. } \\
\text { Pegadaian (Persero). The method used is qualitative } \\
\text { descriptive with five components of COSO to evaluate the } \\
\text { effectivities of internal control that applied at PT. Pegadaian } \\
\text { (Persero). The five components of the COSO internal control } \\
\text { is the control environment, risk assessment, control activities, } \\
\text { information and communication and monitoring. The results } \\
\text { showed that internal control systems at PT. Pegadaian } \\
\text { (Persero) have been support by Standard Operating } \\
\text { Procedures for all operations and filed documents. But from } \\
\text { the evaluation for internal control system of receiving, } \\
\text { returns, and auctions of collateral items there are still task } \\
\text { stacking at unit manager make internal control systems PT. } \\
\text { Pegadaian (persero) still have lack of control. } \\
\text { Keywords: Internal Control Systems, Collateral Item, COSO. }\end{array}$ \\
\hline
\end{tabular}

\section{INTRODUCTION}

As a non-bank financial institution engaged in mortgage loan services, the role of PT. Pegadaian (Persero) which is oriented to help and serve the needs of small-scale communities is very helpful for economic growth. PT. Pegadaian (Persero) helps people who lack funds to be able to meet the need for cash at any time, where people who need funds can come with their personal belongings as collateral to be mortgaged (Siwu, 2013)

Collateral is one of the requirements in applying for a loan at PT. Pegadaian (Persero). The term collateral is the debtor's ability to meet or pay off his allowance to the creditor, which is done by holding certain objects of economic value as dependents on loans or debts received by the debtor against the creditor. Collateral items that can be used as dependents are items 
that can be valued in money, which can be in the form of certain material that is submitted by the debtor to the creditor as a result of a debt agreement or other agreement.

PT. Pegadaian (Persero) provides loans to the public with requiring collateral as a guideline and auctioning collateral that is not repaid until a specified deadline. According to the operational manual of the branch office of PT. Pegadaian (Persero), auction is an effort to repay loans and capital leases, which are not repaid until the specified deadline. This business is carried out by selling these collateral items to the public at the designated time.

PT. Pegadaian (Persero) is required to store and maintain collateral and protect it from damage, defects or loss of part or all of it so that its condition and value are not reduced when the loan money is repaid. One factor is the occurrence of damage, defects, loss of goods as well as various other deviations caused by weak internal control, especially internal control of collateral.

Internal control is very important to achieve several objectives such as efficient and orderly behavior in carrying out the work of its employees, protecting assets, preventing errors and detecting errors, preventing fraud and detecting fraud and increasing accuracy in the completeness, reliability and timeliness of reliable information (Topash, 2014: 40). Therefore, the control of collateral needs to get proportional attention and be carried out professionally for every collateral in PT. Pegadaian (Persero).

The importance of an internal control system for collateral for PT. Pegadaian (Persero) in achieving efficiency and effectiveness, needs to be supported by an evaluation of the application of its internal control system. Therefore, the authors are interested in bringing this up in a study. Based on the background stated earlier, the formulation of the problem in this study is how the application of the internal control system for the receipt, return and auction of collateral at PT. Pegadaian (Persero)?.

\section{LITERATURE REVIEW}

Pawn

PT. Pegadaian (Persero) is one of the non-bank financial institutions provide loans to the community with the aim of assisting government programs in an effort to improve the welfare of the community, especially the lower middle economic groups through the distribution of mortgage loans. The Civil Code Article 1150 states the following liens. "A lien is a right that is obtained by a person who is in debt for a movable object, which is surrendered to him by a person who is in debt or by someone else on his behalf, and who gives the person the loan to take power over time to take off the object in advance. ; with the exception of the costs of auctioning the item and the costs incurred to save it after the item has been pawned, which costs should come first ". A debtor gives the power to the creditor to use the movable property which has been surrendered, if the debtor cannot fulfill his obligations when due.

\section{Guarantee}

Collateral is a responsibility given by the debtor to the creditor. For PT. Pegadaian (Persero), guarantees are very important in the process of loan realization by customers. According to Bahsan (2010: 148), "collateral is Everything that is received by the creditor and submitted by the debtor to guarantee a debt receivable in the community". According to 
Firdaus (2003: 252), "guarantees are all tangible goods owned by the debtor or those owned by other parties with the knowledge and approval of the debtor and submitted by the debtor who gives the debtor the power to take the goods after paid off ".

From the various meanings above, it can be concluded that "collateral is a dependency that can be valued in money, in the form of certain material which is submitted by the debtor to the creditor to obtain loan money".

\section{Internal Control System}

According to Romney and Steinbart (2006: 229), internal control is a plan organization and business methods used to maintain assets, provide accurate and reliable information, encourage and improve the efficiency of the organization's operations and encourage compliance with established policies. Internal control must be carried out as well as possible within a company to prevent and avoid mistakes, fraud and fraud. Another understanding put forward by King quoted by Lakis (2012) is as follows. "Internal control is a process through which the enterprise reaches its goals, results, also plans authority performance, arrangements, monitoring in the whole enterprise or separate subdivisions."

Internal control can also be interpreted as a process where the company achieves its objectives, results, as well as work plans, arrangements, supervision throughout the company or separate subdivisions. Furthermore, the Committee of Sponsoring Organization of the Treadway Commission (COSO) in 1992 issued the definition of internal control as follows (Provitiviti, 2014). "Internal control is a process, effected by an entity's board of directors, management, and other personnel, designed to provide reasonable assurance regarding the achievement of objectives relating to operations, reporting and compliance."

Internal control is a process that involves the board of commissioners, management and those under their directives, to provide reasonable assurance that the objectives of control are achieved by considering the effectiveness and efficiency of the organization's operations, the reliability of financial reporting, and compliance with applicable laws and regulations. applicable. From the above understanding it can be concluded that, the internal control system includes policies and actions taken in an organization involving parties in the organization to regulate and direct the activities of the organization so that the goals set by the company are achieved.

\section{Components of the COSO Internal Control System}

COSO stands for Committee of Sponsoring Organizations of The Treadway Commission is a private sector group consisting of the American Institute of Certified Public Accountants (AICPA), the American Accounting Association (AAA), the International Financial Executives (FEI), The Institute of Internal Auditors (IIA) and The Association of Accountants and Financial Professionals in Business (IMA). The main objective is to identify the factors that cause embezzlement of financial statements and make recommendations for controls, internal standards and criteria that companies can use to assess their control systems. The internal control system consists of five components as follows (Provitiviti, 2014).

a. Control environment

The control environment is the basis for all other internal control components, providing discipline and structure. The control environment is a condition that is built and created in an 
organization that will affect the effectiveness of control. The control environment provides direction for the organization and influences the control awareness of the people in the organization. The control environment consists of the following factors.

1. Commitment to integrity and ethical values.

2. Management's philosophy and operating style.

3. Organizational structure.

4. Audit board and board of commissioners.

5. Methods for giving authority and responsibility.

6. Policies and practices in human resources.

7. External influences.

b. Risk assessment (risk assessment)

Risks are things that have the potential to hinder the achievement of objectives. Risk identification is needed to determine the potential events that can hinder and hinder the realization of organizational goals. Risk assessment is the identification of entities and analysis of relevant risks to achieve their objectives and forms a basis for determining how risks should be managed.

\section{c. Control activities}

Control activities are policies and procedures that help ensure that management directives are implemented. Control activities have a variety of objectives and are applied at various levels of the organization and function. In general, control activities consist of the following matters: (1) authorizing adequate transactions and activities; (2) segregation of duties; (3) adequate design and use of documents and records; (4) safeguarding adequate assets and records; and (5) independent examination of performance.

d. Information and Communication (information and communication)

Information is data that has been managed that is used for decision making in the context of carrying out the duties and functions of the organization. Incorrect information can lead to wrong decisions and policies. Errors of information can occur when data retrieval, data analysis and data conclusions become information and information management. The element of control over information and communication becomes important because of the development of science and technology. Information technology can make internal control more effective and efficient, but on the other hand demands the development of employees' knowledge and skills in information technology.

e. Supervision (monitoring)

Supervision is the process of determining the quality of internal control performance over time. Supervision involves an ongoing process to assess the quality of internal control over time and to take necessary corrective actions. Supervision is achieved through ongoing activities (on going monitoring), separate evaluation (separate evaluation) or a combination of both. On going monitoring activities include management supervision activities and other actions that can be taken to ensure that the internal control process is ongoing effectively. Separate evaluation (separate evaluation) is a periodic assessment of organizational performance with measurement standards that have been agreed upon in advance. 


\section{RESEARCH METHODS}

\section{Types of research}

In this research, the writer uses descriptive research method qualitative. The study was conducted on natural conditions directly to the data source, data collection using research instruments and data collected in the form of organizational structure, job description, company history, company services as well as procedures for receiving, returning and auctioning collateral at PT. Pegadaian (Persero).

\section{Data and Data Sources}

This study uses qualitative data, which is data in the form of words, not in the form of numbers (Kuncoro, 2014). Qualitative data taken such as interviews about the accounting information system and the internal control system for the receipt, return and auction of collateral items at PT. Pegadaian (Persero). Data source in this study in the form of primary data and secondary data. Primary data obtained by collecting it directly such as interviews with employees of PT. Pegadaian (Persero) regarding accounting information systems and internal control systems for the receipt, return and auction of collateral as well as the results of observations of the company's internal control activities. Secondary data in the form of forms, evidence, notes and other company documents obtained from literature and documentation studies.

\section{Operational definition}

In order to avoid mistakes in interpreting this research, it is necessary. There are several relevant operational definitions used in this study, including the following.

a. Evaluation is the evaluation of an object by using one or several measuring tools. In this study is an assessment of the internal control system for the receipt, return and auction of collateral at PT. Pegadaian (Persero) compared to the five components of the COSO internal control system.

b. The intended acceptance is the stage of receiving collateral from the prospective customer to PT. Pegadaian (Persero) when submitting a credit process to the storage of collateral goods.

c. The intended return is the stage of return of goods beginning with the release of the collateral from the storage to the collateral given to the customer when the customer has paid all obligations to PT. Pegadaian (Persero).

d. Auction is an effort to return the loan money along with capital leases, which are not repaid until the specified deadline. This business is carried out by selling these collateral items to the public at the designated time.

e. The intended cash disbursement system is only for cash disbursements when the cashier lends to customers and receives collateral.

f. The intended cash receipt system is only for cash receipts when the customer repays all obligations and issues collateral.

g. The sale system in question is the sale during the auction process.

\section{Data analysis technique}

The data analysis technique used is as follows. 
- Collect qualitative data and study the application of internal control systems for the receipt, return and auction of collateral items at PT. Pegadaian (Persero).

- Evaluating the internal control system that has been implemented by PT. Pegadaian (Persero) whether it is in accordance with the components of the COSO internal control system.

- Draw conclusions and provide advice and input to the PT. Pegadaian (Persero) regarding the system of internal control over the receipt, return and auction of collateral items at PT. Pegadaian (Persero).

\section{FINDINGS AND DISCUSSION}

\section{a. Receipt of Collateral Items and Cash Dispensing System}

Receipt of collateral starts from the application for a mortgage loan by the customer. Procedure for pawning loan applications by customers at PT. Pegadaian (Persero) is as follows. 1. Customer

a) Customers come to the office of PT. Pegadaian (Persero).

b) Take and fill out a Credit Request Form (FPK).

c) Submit the completed Credit Request Form by attaching a photocopy of Identification Card (KTP), Driving License (SIM) or a valid passport and Collateral (BJ) that will be guaranteed.

d) Sign the original and multi-fold Credit Proof (SBK) submitted by the cashier and return the multi-fold SBK to the cashier.

e) Receive original loan and SBK money (sheet 1).

2. Estimator, Storage and Manager of UPC.

a) Receive FPK with attachment of KTP, SIM or passport along with BJ from the customer b) Checking the completeness of the correctness of FPK and BJ collateral guaranteed.

b) Check and match a photocopy of the customer's identity with the original. d. Sign FPK as proof of receipt of BJ from the customer. e. Make an estimate to determine the value of BJ.

c) Decide on the amount of Loans that can be given to customers in accordance with applicable regulations.

d) Submit the signed FPK to the cashier.

e) Storing collateral goods by attaching SBK driver on the Goods Guarantee.

3. Cashier

a) Receive FPK from an estimator or UPC manager. b) Make SBK based on FPK.

b) Carry out payment of mortgage loans and receive multi-fold and SBK driver that has been signed by the customer.

c) Keep multiple SBK as administration.

d) Submit SBK driver to the estimator or UPC manager as an attachment to BJ. Journal at the time of receipt of collateral and cash disbursement at PT. Pegadaian (Persero) as follows.

\section{Goods Return Guarantee and Cash Receipt System}


The return of collateral starts from the procedure for paying off the mortgage by the customer. Procedure for paying off mortgage loans by customers at PT. Pegadaian (Persero) is as follows.

1. Customer

a) Submit the original Credit Proof (SBK), original Identity Card (KTP) and photocopy as well as the amount of money for repayment in accordance with the amount that must be paid to the cashier.

b) Receive Repayment Slip (SP) sheet 1 as proof of payment.

c) Receive collateral that has been repaid.

2. Cashier

a) Receive original SBK, original KTP and photocopy and match for validity.

b) Calculate the amount of repayment money that must be paid by the customer, namely the loan principal and capital rent.

c) Receive payments from customers.

d) Issue and submit Repayment Slip sheet 1 to customers as proof of repayment and Repayment Slip sheet 2 as an archive.

e) Affix the paid stamp, date and initial on the original SBK.

f) Archive original SBK, SBK chauffeur, photocopy of KTP, Repayment slip sheet 2 and Form Credit Request.

\section{Depositors, UPC Managers.}

a) Receive original Credit Proof and check the cash stamp, date and initial of the cashier.

b) Match the original Proof of Credit with the driver's number attached to the collateral item. If it is suitable, hand over the collateral to the customer.

c) At the end of closing time, the office shall match the total amount of collateral redeemed on that day by matching the total receipt of the original Credit Receipt received from the customer with the recapitulation of the settlement made.

d) Noting into related forms.

\section{DISCUSSION}

An internal control is said to be effective when understanding the extent to which the entity's operational objectives are achieved, the published financial statements are prepared reliably, applicable laws and regulations are complied with (Akwaa, 2016). The results showed that the receipt, return and auction of collateral at PT. Pegadaian (Persero) has been carried out based on PT. Pegadaian (Persero) and the accounting records are carried out with the system. An efficient internal control system can be assessed using five components of the COSO, also known as the COSO framework) in evaluating the company's internal control. The five components of the COSO are control environment, risk assessment, control activities, information and communication, and monitoring (Oseifuah, 2015).

\section{a. Evaluation of the Internal Control System for the Receipt of Collateral and Goods Cash Disbursement System}

Based on the results of research on the collateral receipt system and system cash disbursement, the evaluation of the internal control system for the receipt of collateral and the cash disbursement system by considering the five components of the COSO are as follows. 
1. Control environment. The process of assessing gold is only done by employees who have the expertise and competence as an appraiser. The work culture of PT. Pegadaian (Persero) is known by the term INTAN. Each employee has their respective responsibilities and job descriptions. The authorization of the document of proof of credit at the level of the UPC manager is only carried out by one employee and there are concurrent positions where the UPC manager concurrently functions as an estimator and a function of safekeeping goods. The collateral that has been estimated is saved when the office closes and is rechecked based on the loan recapitulation report.

2. Risk assessment (risk assessment). In assessing the risk of the receipt of collateral goods PT. Pegadaian (Persero) provides the appraisal function with special training and has guidance in conducting assessments so that the appraisal function can differentiate between guarantees that are truly gold and not. In storage PT. Pegadaian (Persero) keeps collateral in a special place, is fire resistant and is equipped with a surveillance camera, and the safe is stored by an authorized employee.

3. Control activities. In carrying out the receipt of collateral and cash disbursement systems, the parties involved are the UPC manager and the cashier. Documents related to the procedure for receipt of collateral items are credit request forms (FPK), proof of credit (SBK), warehouse books (BG) and collateral receipt books (BPBJ). All documents relating to the receipt of collateral and cation receipts are kept in a fire resistant safe box and the confidentiality of its customers is maintained. The function of the estimator and authorization in the receipt of collateral is carried out by the UPC manager and the cash disbursement is carried out by the cashier.

4. Information and communication (Information and communication). PT. Pegadaian (Persero) uses a computerized system so that making reports does not require a long time and the information is more reliable. Accounting reports can be made by employees of PT. Pegadaian (Persero) by printing a report in the system. The accounting reports generated in the procedure for receipt of collateral items and the cash disbursement system are loan reports (LP), cash daily reports (LHK), loan recapitulation reports (LRP). loan summary and repayment report (IPP).

5. Supervision (monitoring). The supervision process on the receipt of collateral items and the cash disbursement sstem is carried out by reassessing gold collateral once a month by the branch manager so that it can be monitored if the assessor makes a mistake in assessing and there is supervision from PT. Pegadaian (Persero) which conducts an audit every six months.

A transaction that occurs within a company may not be carried out by one function alone, but there must be interference from other functions. A function may not be given full responsibility for carrying out all stages of a transaction. Good control must have a separation of tasks performed at different levels in a business process (Teru, 2015: 3). The results of the evaluation of the internal control system for the receipt of collateral and cash disbursement systems conducted at PT. Pegadaian (Persero) shows that each function is performed by different employees. As for the branch service unit (UPC), the UPC manager concurrently serves as an appraiser and depositor of collateral and the cashier concurrently serves as cashier and administration. This is contrary to the COSO internal control system, especially in the component of the control activity that requires it segregation of duties (Provitiviti, 2014). Based on an evaluation of the internal control system for collateral receipts and a cash 
disbursement system, several advantages and disadvantages of the existing internal control system can be summarized.

1. The advantages of the internal control system over the procedure for receipt of collateral and the cash disbursement system at PT. Pegadaian (Persero).

a. Strongbox may only be opened by employees who have the authority to store collateral.

b. Often performed calculations and physical inspection of collateral every month by the authorized officer.

c. Storage place for collateral in the form of collateral goods warehouse has been equipped with a good security system.

d. There are reports and documents that support each procedure for receiving collateral.

2. Weaknesses of the internal control system for the procedure for receipt of collateral items and the cash disbursement system at PT. Pegadaian (Persero).

a. Specifically for UPC, there are still multiple positions, namely assessors, warehouse holders and depositors of collateral only carried out by one person, namely the UPC manager.

b. Specifically for the UPC, the authorization system is inadequate because each document is only authorized by one authorized official and not by two authorized officials, namely only authorized by the UPC manager.

c. In practice, the collateral is often not stored in the warehouse after the collateral is received and only left in a drawer. This allows deviation or loss of collateral.

\section{b. Evaluation of the Internal Control System for Returning Guaranteed Goods and Cash Receipt System}

Based on the results of research on the guarantee return and receipt system cash, the evaluation of the internal control system for the return of collateral and the cash receipt system by considering the five components of the COSO are as follows.

1. Control environment. Collateral items will be issued by the depository function when the customer has repaid all of his loans and the collateral taken by the customer must be done by the customer, cannot be represented and must attach identification and carry proof of credit. There is a clear division of tasks between the storage function and the cashier function. Returns of collateral are regulated according to the operational guidelines of the branch office of PT. Pegadaian (Persero). The proof of credit given by the customer at the time of collateral collection will be archived as evidence of returning the collateral by the customer.

2. Risk assessment (risk assessment). In assessing the risk of the return of collateral, PT. Pegadaian (Persero) where the customer must come directly and bring an identification card and proof of credit when taking collateral. Collecting collateral from the safe box must only be carried out by a storage function.

3. Control activities. The return of collateral is carried out by the depository function but for the UPC office because the UPC manager concurrently holds the position as a depository function, the collateral collection from the safe is carried out by the UPC manager. To maintain the accuracy of the information then in repaying loans, customers must carry 
identification cards. The entire process of returning collateral and cash receipts is arranged in the operational guidelines of the branch office of PT. Pegadaian (Persero).

4. Information and communication (Information and communication). Information for management in the form of accounting reports, accounting reports that are generated in the procedure of returning collateral and cash receipts system are loan reports (LP), cash daily reports (LHK), repayment reports (LP), repayment reports (LRP), reports loan and repayment summary (IKP).

5. Supervision (monitoring). The supervision process on the return of collateral and the cash receipt system has two different functions that check the validity of customer documents that repay the loan, namely the cashier function and the depository function. Every day a repayment report is made and the cash daily report is made so that the leadership can check the amount of repayment and the amount of cash received.

The results of the evaluation of the internal control system for the return of collateral and the cash receipt system conducted at PT. Pegadaian (Persero) shows that internal control for the return of collateral and cash receipts in the branch service unit (UPC) is not good. This is because the UPC manager concurrently holds positions as collateral for collateral and the cashier portion also holds positions as cashier and administration. Once again, this is contrary to the COSO internal control system, especially in the component of control activities that require the separation of tasks (Provitiviti, 2014).

Based on evaluation internal control system for the return of collateral and cash receipts, it can summarize some of the advantages and disadvantages of the existing internal control system.

1. The advantages of the internal control system over the return of collateral and the cash disbursement system at PT. Pegadaian (Persero).

a. Safes should only be opened by employees who have the authority to take collateral.

b. Collateral can only be taken by the customer who pawned it, can not be represented and must include identification.

c. There are reports and documents that support each procedure to guarantee collateral returns.

2. Weaknesses of the internal control system for the return procedure guarantee and cash receipt system at PT. Pegadaian (Persero).

a. Specifically for UPC, there are still double positions, namely the warehouse holder and collateral storage are only carried out by one person, namely the UPC manager.

b. Specifically for the UPC, the authorization system is inadequate because each document is only authorized by one authorized official and not by two authorized officials, namely only authorized by the UPC manager.

c. Cashiers who hold concurrent positions with administrative affairs can make internal control weak, especially in cash acceptance procedures at the UPC level.

c.Evaluation of the Internal Control System for Auction of Collateral Items

Based on the results of research on the internal control system of auctioning collateral and the sales system, then the evaluation of the internal control system for the auction of collateral items and the sales system by considering the five components of the COSO are as follows.

1. Control environment. In accordance with the provisions of PT. Pegadaian (Persero) the process of auctioning collateral goods is only done for goods collateral that is past due and until a certain period the customer has not been able to pay it off. The auction is carried out by the 
auctioneer which consists of several people and has a decree as the auctioneer and each auctioneer must authorize each tender report made.

2. Risk assessment (risk assessment). To minimize losses due to bad credit, PT. Pegadaian (Persero) uses an auction system so that the proceeds from the sale of collateral are expected to cover the amount of collateral and loan interest.

3. Control activities. Before conducting the auction, the collateral is re-estimated by the auctioneer in accordance with the provisions of PT. Pegadaian (Persero). The re-assessment is carried out by the auctioneer and each auctioneer has responsibility for the auction process and the collateral that is auctioned. Collateral items that have left the safe are recorded and the proceeds from the sale of collateral are deposited to the cashier at the end of the auction day. If the results of the auction after being reduced by loan money, loan interest and auction fees have more results, the proceeds will be returned to the customer.

4. Information and communication (Information and communication). Before the collateral will be auctioned PT. Pegadaian (Persero) has contacted the customer regarding the payment due date and the grace period given for loan repayment, if until such time the customer does not come to repay the loan, PT. Pegadaian (Persero) will carry out the auction process. At the time of the auction there were no documents submitted to the buyer so there was no supporting evidence during the process of selling and receiving money from the buyer, but the financial statements when the auction was still being made, namely the auction sale list (LDPL) report made by the auctioneer, contained each collateral sold. Often in the auction process there are guarantees that are not sold, then the procedure for auction items that are not sold is as follows. a. For auction guarantee items that are not sold at the time of auction, these items are categorized as re-auctioned goods (BLU) which will be included in the auction re- register list and the items are only traded for resale auctions only once in the auction period (must be able to sold).

b. If in the following period of the auction the BLU is still not auctioned, it is proposed to submit a reduction in the auction price to the relevant officials so that auctioned collateral items can be sold.

5. Supervision (monitoring). The supervision process at auction of collateral items and the sales system is carried out by establishing an auctioneer consisting of a chairman and several members who are responsible for the collateral to be auctioned and prior to the auction, the auctioneer will re-assess.

Based on an evaluation of the internal control system for the auction of goods collateral and sales systems, it can summarize some of the advantages and disadvantages of the existing internal control system.

1. Strengths of the internal control system over the auction of collateral items and systems sales at PT. Pegadaian (Persero).

a. The tender organizer was formed, consisting of the chairman and members of the tender organizer.

b. Before the collateral is auctioned PT. Pegadaian (Persero) contacted the customer to notify the loan payment due date.

c. The collateral is re-estimated before the auction process takes place.

d. Each auctioneer must authorize documents and reports made in the auction process. 
2. Weaknesses of the internal control system for auctioning collateral and sales systems at PT. Pegadaian (Persero).

a. No documents are given to the buyer when the collateral is sold.

b. There is no document given to the customer as proof that the item has been auctioned and the customer does not know how much the price was sold at auction of collateral.

\section{CONCLUSION AND SUGGESTION CONCLUSION}

Based on the results of the discussion regarding the evaluation of the implementation of the control system internship on receipt, return and auction of collateral items at PT. Pegadaian (Persero) by using five COSO components, it can be concluded as follows.

a. Existing internal controls at PT. Pegadaian (Persero) has been supported by clear SOPs and routine checks on collateral that are physically carried out and matched to a notebook.

b. Evaluation of the application of the internal control system for collateral receipts and cash disbursements is still a weakness in controlling PT. Pegadaian (Persero) where there are still multiple positions and authorization by UPC managers, namely appraisers, warehouse holders and depositors of collateral, only one person, namely UPC manager.

c. Evaluation of the application of the internal control system for the return of collateral and cash receipts is still a weakness in controlling PT. Pegadaian (Persero) because there are still multiple positions in the management of the UPC as the holder of the warehouse and deposit of collateral.

d. Evaluation of the application of the internal control system for auctioning collateral items still has weaknesses in controlling PT. Pegadaian (Persero) where no documents are given either to the buyer of the collateral sold, or to the customer whose collateral has been sold.

\section{SUGGESSTION}

Based on the conclusions that have been presented, several conclusions are made advice as follows.

a. There is a need for an appraiser at UPC so that the UPC manager does not hold concurrent positions. Authorization must be carried out according to existing regulations, namely by the appraiser and manager UPC is not only by UPC managers.

b. Collateral must be stored in a safe deposit box and recorded in the relevant documents after the receipt of the collateral process so as to minimize the possibility of fraud.

In the auction process PT. Pegadaian (Persero) should produce evidence to be submitted to the buyer as proof of receipt of money from the buyer and to the customer as well as evidence of collateral items being auctioned and the amount of proceeds from the auctioned goods.

\section{REFERENCE}

Ali, Hapzi, 2019 Internal control 
Akwaa Ellis K, 2016. Effects of Internal Controls on Credit Risk among Listed Spanish Banks. Omnia Science. ISSN 1697-9818. Vol. 12 No. 1. 357-3

Kuncoro, Mudrajad, 2014. Research Methods for Business and Economics, Issue 4. Erlangga. Jakarta. Lakis V, 2012. The Concept of Internal Control System: Theoretical Aspect. Economist, ISSN 1392-1258, Vol. 91 No. 2, 142-152.

Government of the Republic of Indonesia, Civil Code. Government of the Republic of Indonesia, SOE Ministerial Regulation Number Per- 01 / MBU / 2011 concerning Implementation of Good Corporate Governance (Good Corporate

Governance) In State-Owned Enterprises.

Government of the Republic of Indonesia, Government Regulation No. 103 of 2000 concerning Public Corporation (Perum) Pegadaian., Law No. 10 of 1998 concerning Banking. Law No. 23 of 1999 concerning Bank Indonesia.

PT. Pegadaian (Persero). 2012. Branch Office Operational Guidelines. PT. Pegadaian (Persero).Jakarta.

Provitiviti, 2014. The Updated COSO Internal Control Framework, FAQs. Second Edition. Provitiviti Inc, Washington, DC.

Siwu, Fifke M. 2013. Evaluation of the Application of the Internal Control System on the Procedure for Receiving and Returning Guaranteed Goods at PT. Pegadaian (Persero) Kalawat Branch. EMBA Journal, ISSN 2303-1174, Vol. 1 No. 4, 1706-1716.

Teru, Susan P., 2015. Appraisal of Accounting Information Systems and Internal Control Frameworks. International Journal of Scientific and Research Publications, ISSN 2250-3153, Vol. 5 Issue 9, 1-3.

Topash, N. K., 2014. Evaluation of Efficiency of Accounting Information Systems: A Study on Mobile Telecommunication Companies in Bangladesh. Global Disclosure of Economics and Business, Vol. 3 No. 1, pp. 40-55.

Oseifuah Emmanuel, 2015. Internal Control Systems in Small and Medium-sized Medical Practices in Thulamela Municipality, South Africa. Problems and Perspectives in Management. Vol. 13, Issue 4. 215-222 